\title{
Students' Achievement in Physical and Health Education: Effect of Discussion Teaching Method
}

\author{
Linda N. Chukwurah ${ }^{1,2}$, Oliver I. Abbah ${ }^{3}$, Cylia N. Iweama ${ }^{3, *}$, John E. Ogugua ${ }^{4}$, Jonathan Ameh ${ }^{4}$ \\ ${ }^{1}$ Department of Kinesiology, Michigan State University, USA \\ ${ }^{2}$ Department of Human Kinetics and Health Education, University of Nigeria, Nigeria \\ ${ }^{3}$ Department of Human Kinetics and Health Education, UNN, Nigeria \\ ${ }^{4}$ Department of Human Kinetics and Health Education, Faculty of Education, University of Nigeria, Nigeria
}

Received March 10, 2020; Revised April 21, 2020; Accepted May 3, 2020

Copyright $(2020$ by authors, all rights reserved. Authors agree that this article remains permanently open access under the terms of the Creative Commons Attribution License 4.0 International License

\begin{abstract}
Recently, poor results have been recorded by students in Physical and Health Education in external examinations. This situation may be attributed to the teaching methods adopted by the teachers. Therefore, this study ascertains the effect of discussion teaching method on junior secondary school students' achievement in PHE. Two null hypotheses were postulated. Quasi-experimental non-equivalent control group pre-test post-test design was adopted. Using purposive sampling, two co-educational schools in Nsukka L.G.A. were selected of which experimental and control clusters was determined through balloting. The sample consisted of forty JSS2 students from two intact classes of 20 students each. Physical Education Achievement Test was used for data collection. Pre-test data were collected from both clusters as baseline data before the experimental cluster was exposed to the teaching method. At the end 8 weeks, post-tests data were collected using same instrument to determine the effect of discussion teaching method on the students' achievement. The null hypotheses were tested using ANCOVA at .05 level of probability. From the results, the experimental cluster attained higher Mean Gain, and discussion teaching method enhanced the students' achievement $(p=.007)$. However, no significant difference was found based on gender $(p=.088)$. The study concludes that discussion teaching method is very effective in the teaching and learning of PHE in theory, therefore, the subject should be structured towards active and participatory learning. Also, PHE teachers should be re-trained on the job and more time should be allotted to PHE in the schools to enable effective application of discussion teaching method.
\end{abstract}

Keywords Junior Secondary School, Universal Basic Education, West African Examination Council

\section{Introduction}

Physical and Health Education (PHE) is an integral part of education which plays vital role in the overall wellbeing of students. In Nigeria, the junior secondary school's physical and health education curriculum is designed to continue students' investigation into natural phenomena, to deepen students' understanding of the subject and also encourage students' ability to apply knowledge to everyday life in matters of personal, community, health and agriculture among others [6].

Students' success in PHE depends largely on the learning process which teaching method is a greater part of. According to [1], students' achievement is qualified by measure of students' academic standing in relation same age bracket. However, students' achievement in physical and health education in external examination has not been above average. A sample of students' West African Examination Council results in PHE in the study area between $2010-2015$ shows that majority of the students obtained grades with the range of pass (D7) to outright failure (F9) $[13,9]$. This indicates poor achievement in PHE being that the least requirement for further studies in PHE and related courses is a Credit (C6) score. This situation may be heavily linked to the use of traditional teaching method in the delivery of PHE learning process $[13,9]$.

Among different teaching methods, discussion teaching method seems to be most recently advocated for, because of its effectiveness. Discussion teaching method is an instructional strategy that involves teachers and students sharing ideas on a topic. It is a strategy that utilizes the interaction of lecturer-students and among students as the primary means of achieving learning objectives [5]. This method of teaching and learning avails students the opportunity to freely interact with the teacher for clearer understanding of activities and lessons. In this method of teaching, students learn to use their voice, listen carefully 
and respectfully to the voice of other students [20] and as well as enhance learning in general, where such learning is associated with both the individual student and the class as a whole [14].

In Nigeria, there is emphasis for student-centered (interactive) learning, and the use of discussion teaching method has been intensified with the introduction of Universal Basic Education (UBE) scheme in 2004 which aims at eliciting high cognitive process in students [6]. Despite the above efforts to enhance the effectiveness of teaching and learning experiences in secondary education level in Nigeria, students still perform below average in PHE external examination. Furthermore, on gender, researcher such as [17] mentioned that some teaching methods that involve students' competition such as individual learning favour male students more than female students while other teaching methods that encompass interactive learning favours females more than males. Therefore, the present study seeks to ascertain the effectiveness of discussion teaching in theory PHE subject and if the effectiveness of the teaching method differs based on gender of the PHE students.

Situating this study is cognitive theory by Piaget. The theory stresses the acquisition of knowledge and skills, formation of mental structures and processing of information and belief [3]. Cognitivists acknowledge that environmental conditions play important role in the learning process. By implication, PHE teachers in order to enhance learning of the subject should create conducive environment capable of improving the learning process. Such situation can be created through structured interaction between the teacher and students whereby necessary feedback is promptly delivered like in discussion teaching method. In addition, current learning is built on previous acquired knowledge by learners on a subject-matter; therefore, the most efficient way a PHE can probe previous knowledge of students on a topic and build learning process is by engaging the students in structured discussions of topics. Therefore, the study aims to ascertain the following:

\subsection{Research Hypotheses}

HO1: There is no significant difference in the mean achievement scores of junior secondary school students taught PHE with discussion teaching method and those taught with the traditional teaching method.

HO2: There is no significant difference in the achievement scores of junior secondary school students taught PHE with discussion teaching and traditional teaching method based on gender.

\section{Methods}

\subsection{Study Area and Duration}

The study was conducted in Nsukka L.G.A. of Enugu state, south-east Nigeria between August 2019 to February, 2020. The local government comprised of many secondary schools both private and government owned secondary schools. Additionally, there are both same sex and co-educational (boys and girls) secondary schools. Though both the private and government owned secondary schools offer Physical and Health Education (PHE) as a subject at the junior secondary school (JSS) level, it is only the government-owned school that employs qualified PHE teachers to teach the subject. These schools participate in Junior secondary school West Africa Council Examination and over time, their performances have been below average. Considering the fact that lots of efforts are continually being made to ensure adequate provision of facilities and equipment in the government-owned schools for PHE subject, there is still no visible improvement in their performance in external examination such as Junior secondary WAEC unlike in other subjects in recent times. This situation may arise because of the teaching method of PHE teachers in the various schools, therefore, the rationale for the present study.

\subsection{Design}

Quasi-experimental pre-test post-test research design was employed in the study. The design was adopted to investigate students' achievement in Physical and Health Education: Effect of discussion teaching method among junior secondary school students in Nsukka local government area of Enugu State, Nigeria.

\subsection{Participants}

The sample sizes of forty (40) junior secondary 2 (JS 2) students of two intact classes were used for the study. This is because the study took place in a normal school term. From the co-educational schools in the local government area, two schools were purposively selected because of their acceptance, location and quality of the teachers. The choice of co-educational schools was because gender was a variable tested in the study. Through randomization, the schools were assigned to experimental and control cluster ( $n=20$ for each cluster).

\subsection{Instrument}

Physical and Health Education Achievement Test (PHEAT) and Lesson Plan schedule were used for data collection. PHEAT was structured using West African Junior School Certificate Examination past questions. Validation of PHEAT was done by professionals in Physical education, Measurement and Evaluation and Health Education. The questions are standardized test and so were not subjected to further reliability test.

\subsection{Procedure}

In order to control for Hawthorne effect, the regular 
Physical and Health Education teachers in the schools were used for the study. These are certified teachers employed and teaching PHE subject in the schools. The teachers were briefly trained on the research protocol, however, teachers in the experimental cluster were further trained on the teaching method. Pre-test data were collected from the two clusters which served as baseline data for the study. To control for testing effect that may sensitize the subjects in an unanticipated way that the post-test result would be due to the pre-test, none of the students received feedback on achievement after the pre-test. Enrolment of the two clusters (experimental and control) were conducted simultaneously and within the school timetable. In order to control for natural maturation process among the subjects, no time was allowed after the intervention and post-test. Therefore, at the end of 8weeks of teaching, post-test data were collected using same instrument (PHEAT) to determine the effect of discussion teaching method on the achievement of junior secondary students in Physical and Health Education.

\subsection{Data Analysis}

Results were recorded and analysis of the data was done using the Statistical Package for Social Sciences (SPSS) version 21. Analysis of Co-Variance (ANCOVA) was used to test the null hypotheses at .05 level of significance. Therefore, if $\mathrm{p}$-value is less than .05 (p-value $<.05$ ), the null hypothesis is rejected, otherwise, the hypothesis is not rejected if $\mathrm{p}$-value $>.05$.

\section{Results}

Table 1 shows that the experimental group attained higher Mean Gain (MG) than the control group. However, there seems not to be a big gap in the mean gains of the two groups.

Table 2 presents data in the significant difference in mean achievement scores of the students taught PHE with discussion teaching method and those taught with the traditional teaching method. The table clearly shows that there was a significant difference between the experimental group and control group in their mean PHE achievement post-test scores (p-value $.007<.05$ ).

Table 3 shows that there was no significant difference between the male and female JSS 2 students in the experimental and control groups in their mean achievement scores in PHE (p-value .088 > .05).

Table 1. Mean and Standard Deviations of Achievement Scores of JSS 2 Students ( $\mathrm{n}=40)$

\begin{tabular}{|c|c|c|c|c|c|c|}
\hline \multirow{2}{*}{ Groups } & \multirow{2}{*}{$\mathbf{N}$} & \multicolumn{2}{|c|}{ Pre-test } & \multicolumn{2}{|c|}{ Post-test } & \multirow{2}{*}{ MG } \\
\cline { 3 - 7 } & & $\bar{x}$ & SD & $\bar{x}$ & SD & \\
\hline Experimental & 20 & 8.95 & 4.74 & 15.65 & 2.76 & 6.70 \\
\hline Control & 20 & 11.60 & 4.04 & 17.90 & 2.43 & 6.30 \\
\hline
\end{tabular}

Table 2. Effect of Discussion Teaching Method on Achievement of JSS Students in PHE $(n=40)$

\begin{tabular}{|c|c|c|c|c|c|c|}
\hline Source & Type Sum of squares & Df & Mean Square & F & Sig. & Partial Eta Squared \\
\hline Corrected Model & $56.378^{\mathrm{a}}$ & 2 & 28.189 & 4.162 & .023 & .184 \\
\hline Intercept & 1859.948 & 1 & 1859.948 & 274.617 & .000 & .881 \\
\hline Pre-test & 5.753 & 1 & 5.753 & .849 & .363 & .007 \\
Group & 56.341 & 1 & 56.341 & & \\
Error & 250.597 & 37 & 40.773 & & \\
Total & 11563.000 & 39 & & & \\
Corrected Total & 306.975 & & & & \\
\hline
\end{tabular}

Table 3. Effects of gender and discussion teaching method on students' achievement in PHE ( $\mathrm{n}=40)$

\begin{tabular}{|c|c|c|c|c|c|c|}
\hline Source & Type Sum of squares & Df & Mean Square & $\mathbf{F}$ & Sig. & Partial Eta Squared \\
\hline Corrected Model & $137.710^{\mathrm{a}}$ & 4 & 34.427 & 7.119 & .000 & .449 \\
\hline Intercept & 1683.695 & 1 & 1683.695 & 348.148 & .000 & .909 \\
\hline Pre-test & 1.235 & 1 & 1.235 & .255 & .616 & .007 \\
\hline $\begin{array}{c}\text { Group } \\
\text { Gender } \\
\text { Group*Gender } \\
\text { Error } \\
\text { Total } \\
\text { Corrected Total }\end{array}$ & $\begin{array}{c}50.674 \\
63.600 \\
16.361 \\
169.265 \\
11563.000 \\
306.975\end{array}$ & $\begin{array}{c}1 \\
1 \\
1 \\
35 \\
40 \\
39\end{array}$ & $\begin{array}{c}50.674 \\
63.600 \\
16.361 \\
4.836\end{array}$ & $\begin{array}{c}10.478 \\
13.151 \\
3.383\end{array}$ & $\begin{array}{l}.003 \\
.001 \\
.074\end{array}$ & $\begin{array}{l}.230 \\
.273 \\
.088\end{array}$ \\
\hline
\end{tabular}




\section{Discussion}

From the results, the experimental cluster achieved a higher Mean Gain than the control cluster. This clearly shows that the utilization of discussion teaching method greatly impacted the experimental cluster to perform better in the subject. This is therefore an indication that classroom interactions and guidance by teachers or instructors enhance effective learning and retention among PHE students. The finding agrees with [17] who found that the three (3) interaction patterns: co-operative, competitive and individualistic patterns enhanced students' achievement and interest in biology.

The significant difference in the mean achievement scores of the JS students taught PHE using discussion teaching method and the traditional teaching shows that the discussion teaching method significantly improved the students' achievement in PHE. This result shows that activity- oriented teaching and learning method helps students to build more interest in a subject. Also, situations that allow students to share their experiences and ideas enhance their problem-solving capabilities in the classroom and beyond. This is supported by $[8,12]$ who found that active teaching techniques increase verbalize and memorization of concepts among students. [10] also found that discussion teaching method provides good opportunity for students to interact with the teacher which aids their learning.

The study recorded no significant difference in the mean achievement scores of male and female students taught PHE using discussion teaching method. This is because both the male and female students did not perform better than each other in the subject. This result implies that gender has no significant effect on the students' achievement in PHE. This result is not expected because male students from history are inclined to activities or subjects that avail them the opportunity to display their physical prowess of which major part of PHE is all about. This also shows that female students are bracing up and beginning to break-through the numerous barriers that hindered their participation the sports and PHE in the past. This result agrees with the findings of [19] and [15] who found that gender has no significant effect on students' academic achievement. However, some studies such as [16]) and [18] found that gender interact significantly on the academic performance of students.

\section{Conclusions}

From the findings of the study, it can be concluded that discussion teaching method plays an important role in facilitating academic performance of students in PHE through participatory learning processes. Therefore, it is very pertinent that urgent steps are taken to ensure the effective utilization of discussion teaching method by PHE teachers in order to improve academic outcome of the students in physical education theory and as well enhance the appreciation of the subject as wholesome tool for all-round development of the students.

Gender not asserting significant difference on the teaching method indicates that both male and female students would perform excellently in theory aspect of physical education under a teacher that is efficient in the utilization discussion teaching method in the delivery of PHE lessons. Moreover, more time should be allotted to physical and health subject to ensure effective utilization of discussion teaching method while re-training of PHE teachers on the utilization of the teaching method should be conducted through workshops and seminars at all levels.

\section{Acknowledgements}

We wish to acknowledge all our research assistants for their cooperation and hard work

\section{Funding}

No form of funding was received for this study

\section{Data and Materials}

The data that support the findings of this study are from different datasets such as Google, Google Scholar and institution's Library.

\section{Author's Contributions}

LC \& CI designed the research work, JA, OA \& JO carried out the data collection. LC, OA \& CI contributed to the data analysis and drafted the manuscript. All the authors read and approved the final manuscript.

\section{Ethics Approval and Consent to Participate}

Both oral and Principal's consents were obtained before carrying out the study. The local institutional research ethics committee, University of Nigeria, Nsukka, approved the study procedure before the study was conducted.

\section{Competing Interest}

The authors declare that they have no competing interests 


\section{REFERENCES}

[1] G. U. Anne. Home Economics and the academic performance of a child, Journal of Home Economics, Vol. 6, No. 1, 99-103, 2005

[2] L. Cohen, L. Manion, K. Morrison. Research methods in education, USA, Routledge, 2011.

[3] D. H. Chunk. Learning Theories: An Educational Perspective, Boston, Pearson Education, Inc, 2012.

[4] G. E. Dallal, The little handbook of statistical practice, Online

available from Retrieved http://jerrydalla.com $/<\mathrm{HSP} /$ pval.ht m 2008

[5] P. Eggen, D. Kauchak. Strategic and models for teachers: teaching content and teaching skills, Boston, Pearson Education, Inc, 2012.

[6] Federal Ministry of Education. The Development of Education, National Report of Nigeria, Abuja, Federal Ministry of Education, 2008

[7] Federal Ministry of Education. Senior Secondary School Curriculum physical education, Abuja, Nigeria Educational Research and Development Council (NEDRC), 2012.

[8] J. Hackathorn, E. D. Solomon, L. Blankmeyer, R. E. Tennial, A. M. Garczynski. Effectiveness of four teaching techniques: Lecture, demonstration, discussions and in-class activities, The Journal of Effective Teaching, Vol. 11, No. 2, 40-54, 2011.

[9] M. Isiugo-Abanihe, L. Ifeoma, I. Tandi, I. Evaluation of the Methodology Aspect of Science Teacher Education Curriculum in Nigeria, Pakistan Journal of Social Sciences Vol. 17, No. 2, 170-176, 2010.

[10] A. Khalid, S. Muhamad, A. Asmaa, J. Wafa. The use of the discussion method at university: Enhancement of teaching and learning, International Journal of Higher Education, Vol. 7, No. 6, 118-128, 2018.

[11] E. K. J. Kirui. The implementation of physical education curriculum in secondary schools: A case of secondary schools in Bomet District. Mphil Thesis: Eldoret - Moi
University, 2007.

[12] D. A. Lake. Students' performance and perceptions of a lecture-based course compared with the same course utilizing group discussions, Physical Therapy, Vol. 81, No. 3, 896-902, 2011.

[13] C. R. Nwagbo. Effects of two Teaching Methods on the Achievement in and Attitude to Biology of Students of Different Levels of Scientific Literacy, International Journal of Educational Research, 216-229, 2006.

[14] M. Nystrand, L. L. Wu, A. Gamoran, S. Zeiser, D. Long. Questions in time: Investigating the structure and dynamics of unfolding classroom discourse, Discourse Processes, Vol. 35, No. 2, 135-198, 2013.

[15] J. Obidile, H. E. Uzoekwe. Influence of gender on accounting students' academic achievement and retention in secondary schools in Anambra state, Nigeria, African Research Review, Vol. 12, No. 4, 87-94, 2018.

[16] I. A. Odaboy. The effect of gender on the achievement of students in Biology using the Jisgaw method, Journal of Education and Practice, Vol. 6, No. 17, 176-179

[17] A. U. Okoro. 2011. Effects of interaction patterns on achievement and interest in Biology among secondary school students in Enugu state, Nigeria, Thesis Department of Science Education, University of Nigeria, Nsukka, 2011.

[18] F. A. Okwo, S. Otunba, S. Influence of gender and cognitive styles in science achievement in physics essay tests, Journal of Science Teachers Association of Nigeria, Vol. 42, No. 1, 85-88, 2007.

[19] E. M. Omwirhiren. Enhancing academic achievement and retention in senior secondary school chemistry through discussion and lecture methods: A case study of some selected secondary schools in Gboko, Benue state, Nigeria, Journal of Education and Practice, Vol. 6, No. 21, 155-161, 2015.

[20] L. B. Resnick, S. Michaels, C. O’Connor, C. How (well structured) talk builds the mind. In D. Preiss \& R.J. Sternberg (Eds). Innovation in educational psychology: Perspectives on learning, teaching and human development (pp 163-194), New York, NY, Springer, 2010. 